\title{
Diversity of aerobic spore-forming bacteria isolated from fresh bee pollen intended for human consumption in Argentina
}

\author{
Adriana M. Alippi ${ }^{\mathrm{a}, \mathrm{b}}$ (D), Leticia A. Fernández ${ }^{\mathrm{c}, \mathrm{d}}$ (D) and Ana C. López ${ }^{\mathrm{a}, \mathrm{e}}$ (D) \\ a Unidad de Bacteriología, Centro de Investigaciones de Fitopatología, Facultad de Ciencias Agrarias y Forestales, Universidad

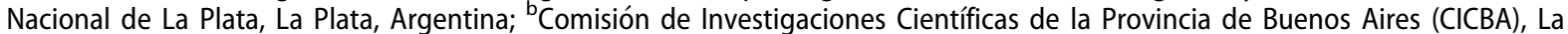 \\ Plata, Argentina; 'Laboratorio de Estudios Apícolas (LabEA-CIC), Departamento de Agronomía, Universidad Nacional del Sur, \\ Bahía Blanca, Argentina; 'Departamento de Biología, Bioquímica y Farmacia, Universidad Nacional del Sur, Bahía Blanca,

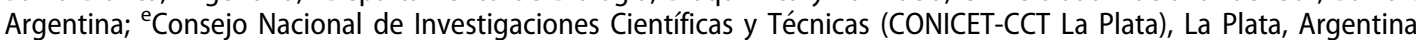

\begin{abstract}
Bee pollen is the result of the agglutination of pollen grains collected from flowers and mixed with nectar and salivary secretions by honey bees. Bee pollen is a natural product exposed to environmental conditions and also provides a unique microhabitat for yeasts and bacterial communities. We analyzed 30 fresh bee pollen samples obtained from the main producing areas of Argentina to identify aerobic-spore-forming bacteria. We obtained 73 isolates belonging to 16 different species through isolation on selective and differential media, morphological and biochemical tests, and PCR and RFLP analysis of genes encoding 16S rRNA. Our data revealed that Bacillus cereus sensu stricto was the most predominant species (50\%), followed by Bacillus megaterium (40\%) and Bacillus subtilis (40\%), respectively. In a minor proportion, Paenibacillus polymyxa (20\%), Paenibacillus larvae (17\%), Bacillus pumilus (13\%), Bacillus licheniformis (13\%), Bacillus amyloliquefaciens (10\%), Lysinibacillus sphaericus (7\%), Bacillus coagulans (7\%), Rummelliibacillus stabekisii (7\%), Bacillus thuringiensis (7\%), Bacillus clausii (3\%), Paenibacillus alvei (3\%), Bacillus simplex (3\%), and Paenibacillus amylolyticus (3\%) were also found. Our results showed that Argentinean bee pollen could transmit honey bee diseases due to the presence of viable spores of $P$. larvae and also spores of toxicogenic B. cereus s.s. and B. megaterium strains.
\end{abstract}

\section{ARTICLE HISTORY}

Received 7 January 2021

Accepted 24 April 2021

\section{KEYWORDS}

Bee pollen; Bacillus; Brevibacillus; Lysinibacillus; Paenibacillus;

Rummeliibacillus; Argentina

\section{Introduction}

Honey bees (Apis mellifera L.) collect pollen from different flower sources during collecting trips and mix them with nectar and salivary secretions (Bertoncelj et al., 2018; Denisow \& Denisow-Pietrzyk, 2016). These pollen loads are referred to as bee pollen which is stored inside the hive separately from the nectar cells (Almeida-Muradian et al., 2005; Rzepecka-Stojko et al., 2015). Beekeepers recover pollen by using bee pollen traps and is, therefore, a wild product without manipulation (Campos et al., 2010; Denisow \& Denisow-Pietrzyk, 2016).

In a recent review, pollen is described as "a new health-oriented product" (Kieliszek et al., 2018), containing proteins, carbohydrates, lipids, vitamins, minerals, crude fiber, flavonoids, carotenoids, enzymes, and free amino acids (Margăoăn et al., 2010). Bee pollen is also considered a functional food with demonstrated physiological benefits as improving health and reducing disease risk (Soares de Arruda et al., 2017). Bee pollen may be consumed fresh or after drying at $40-50{ }^{\circ} \mathrm{C}$, which reduces microbial spoilage and assure long-term stability and safety. However, drying may potentially affect their organoleptic features and content of polyphenols and flavonoids. Alternatively, freezing could be used to preserve pollen's sensorial and nutritional characteristics (Mauriello et al., 2017). Currently, researchers have focused on utilizing bee pollen in food systems as a functional component to enhance product quality characteristics. However, bee pollen is still a new term in many developing countries where even the beekeepers are unaware of their potential as healthy food or functional ingredients, or dietary supplements (Thakur \& Nanda, 2020).

As being very hygroscopic, pollen's water content is affected by climatic conditions; therefore, a risk of microbiological contamination, mainly by molds and yeast, exists (Bertoncelj et al., 2018; Denisow \& Denisow-Pietrzyk, 2016). Also, due to its structure and nutritional composition, bee pollen provides a unique microhabitat for yeasts and bacterial communities, mainly Proteobacteria, Actinobacteria, and Firmicutes (Ambika Manirajan et al., 2016; Moreno Andrade et al, 2018). Within Firmicutes, spore-forming bacteria can survive in pollen grains for several months, and some representatives of this group are pathogens, i.e., Paenibacillus larvae, the causal agent of American foulbrood disease of honey bee larvae (AFB) (de Sousa 
Pereira et al., 2019; Genersch, 2010; Gochnauer \& Corner, 1974; Moreno Andrade et al., 2019; Šekulja et al., 2014); Bacillus cereus, the etiological agent of gastrointestinal diseases in humans (Álvarez Hidalgo et al., 2020; Fernández et al., 2020; Hernández Flores et al., 2020; López et al., 2020; Stenfors Arnesen et al., 2008), Bacillus megaterium (Álvarez Hidalgo et al., 2020; Gilliam, 1979; Gilliam et al., 1990; Hernández Flores et al., 2020; Hosny et al., 2018; López et al., 2013; López \& Alippi, 2010); and Clostridium botulinum that produces several toxins to humans (Gücükoğlu et al., 2020; Johnson \& Bradshaw, 2001).

González et al. (2005) studying the mycobiota of fresh bee pollen in Spain and Argentina concluded that the most critical stage is pollen collection from traps, mainly if the collection is delayed for a long time, favoring fungal growth and mycotoxin production. Other researches evidenced high counts of bacteria, fungi, and yeasts in fresh bee pollen with the consequent risk for human health (Bucio Villalobos et al., 2014; Dinkov, 2018; Feás et al., 2012; Puig-Peña et al., 2012). Several authors stated that flowers contained a unique microbiota different from other aerial plant parts independent from environmental conditions and plant speciesspecific (Ambika Manirajan et al., 2016; Junker \& Keller, 2015; Obersteiner et al., 2016).

Within this context, the study of the microbiota of bee pollen takes relevance to ensure fresh bee pollen's safety for human consumption. We have previously investigated the microbiological and chemical characterization of 36 bee pollen samples from beekeepers of South West of Buenos Aires Province, Argentina, at four sampling points of the production process (Fernández et al., 2020). Moreover, we studied the traceability of potential enterotoxic Bacillus cereus strains showing that bee pollen could be contaminated at any point in the production process, emphasizing the importance of hygienic processing to avoid spore contamination (López et al., 2020).

The present work aimed to identify the aerobic spore-forming species existing in the microbiota of fresh bee pollen samples intended for human consumption obtained in the main producing areas of Argentina. We report the identification of 16 different species of aerobic-spore forming bacterial through isolation on selective and differential media, morphological and biochemical tests, and PCR and RFLP analysis of genes encoding $16 \mathrm{~S}$ rRNA.

\section{Materials and methods}

\section{Pollen samples and isolation of spore- forming bacteria}

A total of 30 bee pollen samples were freshly obtained from beekeepers from different producing areas of Argentina, i.e., Bahía Blanca $(\mathrm{N}=18)$, Villa Iris $(\mathrm{N}=2)$,
H. Ascasubi $(\mathrm{N}=1)$; Mar del Plata $(\mathrm{N}=2)$; delta Río de la Plata $(\mathrm{N}=1)$; La Plata $(\mathrm{N}=1)$; Villarino $(\mathrm{N}=1)$ (Buenos Aires Province); Puerto Madryn $(\mathrm{N}=2)$ (Chubut Province); and Santiago del Estero $(\mathrm{N}=2)$ (Santiago del Estero Province) (Table 1). All the samples were transported to the laboratory and stored at $4{ }^{\circ} \mathrm{C}$ until testing within seven days of receiving.

For isolation of spore-forming bacteria, $1 \mathrm{~g}$ of pollen grains per sample was mixed with $9 \mathrm{ml}$ of $0.01 \mathrm{M}$ sodium phosphate buffer saline $(\mathrm{pH} 7.2)$, agitated for $40 \mathrm{~min}$, and filtered through Whatman \# 3 to a sterile $15-\mathrm{ml}$ Falcon $^{\mathrm{TM}}$ centrifuge tube. Tubes were centrifuged at $9500 \mathrm{~g}$ for $30 \mathrm{~min}$ at $4{ }^{\circ} \mathrm{C}$, and the supernatant was discarded to leave $3 \mathrm{ml}$ of fluid. Tubes were vortex-mixed for $2 \mathrm{~min}$ and thermally treated at $80^{\circ} \mathrm{C}$ for $10 \mathrm{~min}$. Aliquots of $100 \mu \mathrm{l}$ each were plated by duplicate over the surface of MYPGP agar (Dingman \& Stahly, 1983) supplemented with $6 \mu \mathrm{g} / \mathrm{ml}$ nalidixic acid and $10 \mu \mathrm{g} / \mathrm{ml}$ pipemidic acid for the isolation of Paenibacillus larvae (de Graaf et al., 2013; OIE, 2018), and HiChrome Bacillus agar for isolation of the rest of spore-forming bacteria, respectively. Plates were incubated at $37^{\circ} \mathrm{C}$ under microaerophilic conditions ( $5 \% \mathrm{CO}_{2}$ in air) for MYPGP, and under aerobic conditions for Hichrome. Plates were examined daily until bacterial growth developed (up to three days for Hicrome and up to 15 days for MYPGP) and colony counts were made. The number of colonies was averaged, and the total colony-forming units (CFUs) were calculated per $\mathrm{g}$ of pollen (CFU/g).

\section{Identification of bacterial species}

Colony characteristics and media appearance in HiCrome Bacillus agar were evaluated as previously described (Alippi, 2019; Alippi \& Abrahamovich, 2019). The set of morphological and biochemical tests recommended for the identification of spore-forming species isolated from honey samples was used (Alippi, 2019; Alippi \& Abrahamovich, 2019). Additionally, a PCRRFLP assay using universal primers 27f/1492r and a combination of Alul, Cfol, and Taql restriction enzymes were used to differentiate between species of Bacillus, Paenibacillus, Brevibacillus, Lysinibacillus, and Rummeliibacillus (López \& Alippi, 2019). For the identification of Paenibacillus larvae, typical colonies grown in MYPGP semi-selective medium, i.e., small, regular, mostly rough, flat, or raised and whitish to beige colored colonies and catalase-negative (de Graaf et al. 2013; OIE, 2018) were selected. Genomic DNA was extracted from bacterial colonies by using Chelex ${ }^{\circledR}-100$ resin (Alippi \& Aguilar, 1998). Identity was confirmed by PCR by using PL1 and PL2 primers and conditions previously described (Govan et al., 1999; OIE, 2018). 
Table 1. Sources of bee pollen, species identification, and colony-forming units (CFU) obtained per gram of sample.

\begin{tabular}{|c|c|c|c|c|}
\hline Sample & Geographical Origin & Species & $\mathrm{CFU} / \mathrm{g}$ & Total CFU/g \\
\hline P01 & Bahía Blanca (Buenos Aires) & $\begin{array}{c}\text { B. amyloliquefaciens } \\
\text { B. cereus s.s. } \\
\text { B. clausii } \\
\text { B. megaterium } \\
\text { B. pumilus } \\
\text { B. subtilis }\end{array}$ & $\begin{array}{l}30 \\
30 \\
30 \\
30 \\
30 \\
60\end{array}$ & 210 \\
\hline $\mathrm{PO} 2$ & Bahía Blanca (Buenos Aires) & $\begin{array}{l}\text { B. cereus s.s. } \\
\text { B. megaterium }\end{array}$ & $\begin{array}{l}30 \\
30\end{array}$ & 60 \\
\hline PO3 & Bahía Blanca (Buenos Aires & $\begin{array}{l}\text { B. cereus } \\
\text { B. licheniformis } \\
\text { B. megaterium }\end{array}$ & $\begin{array}{l}30 \\
30 \\
30\end{array}$ & 90 \\
\hline P06 & Bahía Blanca (Buenos Aires) & $\begin{array}{l}\text { B. cereus s.s. } \\
\text { B. coagulans } \\
\text { B. megaterium } \\
\text { B. pumilus } \\
\text { B. subtilis } \\
\text { P. larvae }\end{array}$ & $\begin{array}{l}30 \\
30 \\
30 \\
30 \\
30 \\
60\end{array}$ & 210 \\
\hline P08 & Bahía Blanca (Buenos Aires) & $\begin{array}{l}\text { B. cereus s.s. } \\
\text { B. megaterium }\end{array}$ & $\begin{array}{c}90 \\
180\end{array}$ & 270 \\
\hline P09 & Bahía Blanca (Buenos Aires) & B. cereus s.s. & 660 & 660 \\
\hline P010 & Bahía Blanca (Buenos Aires & $\begin{array}{l}\text { B. cereus s.s. } \\
\text { P. larvae }\end{array}$ & $\begin{array}{c}2,040 \\
30\end{array}$ & 2070 \\
\hline P011 & Bahía Blanca (Buenos Aires) & $\begin{array}{l}\text { B. cereus s.s. } \\
\text { P. larvae } \\
\text { P. polymyxa }\end{array}$ & $\begin{array}{c}630 \\
30 \\
30\end{array}$ & 720 \\
\hline P012 & Bahía Blanca (Buenos Aires) & B. megaterium & 60 & 60 \\
\hline P013 & Bahía Blanca (Buenos Aires & $\begin{array}{l}\text { B. cereus s.s. } \\
\text { P. polymyxa }\end{array}$ & $\begin{array}{l}60 \\
30\end{array}$ & 90 \\
\hline P014 & Bahía Blanca (Buenos Aires) & $\begin{array}{l}\text { B. pumilus } \\
\text { B. subtilis }\end{array}$ & $\begin{array}{l}30 \\
90\end{array}$ & 120 \\
\hline P015 & Villa Iris (Buenos Aires) & L. sphaericus & 60 & 60 \\
\hline P016 & Bahía Blanca (Buenos Aires) & B. cereus s.s. & 90 & 90 \\
\hline P065 & Puerto Madryn (Chubut) & $\begin{array}{l}\text { B. cereus s.s. } \\
\text { B. subtilis }\end{array}$ & $\begin{array}{c}90 \\
120\end{array}$ & 210 \\
\hline P066 & H. Ascasubi (Buenos Aires) & $\begin{array}{l}\text { B. megaterium } \\
\text { B. subtilis }\end{array}$ & $\begin{array}{l}30 \\
30\end{array}$ & 60 \\
\hline P067 & Bahía Blanca (Buenos Aires) & $\begin{array}{l}\text { B. subtilis } \\
\text { P. larvae }\end{array}$ & $\begin{array}{c}270 \\
30\end{array}$ & 300 \\
\hline P068 & Bahía Blanca (Buenos Aires) & $\begin{array}{c}\text { B. amyloliquefaciens } \\
\text { P. polymyxa }\end{array}$ & $\begin{array}{l}30 \\
30\end{array}$ & 60 \\
\hline P069 & Bahía Blanca (Buenos Aires) & $\begin{array}{l}\text { B. cereus s.s. } \\
\text { P. larvae }\end{array}$ & $\begin{array}{l}60 \\
30\end{array}$ & 90 \\
\hline P070 & Bahía Blanca (Buenos Aires) & $\begin{array}{l}\text { B. cereus s.s. } \\
\text { B. subtilis } \\
\text { P. polymyxa }\end{array}$ & $\begin{array}{l}60 \\
30 \\
30\end{array}$ & 120 \\
\hline P071 & Delta Río de La Plata (Buenos Aires) & $\begin{array}{l}\text { B. licheniformis } \\
\text { B. subtilis } \\
\text { P. polymyxa }\end{array}$ & $\begin{array}{l}30 \\
30 \\
30\end{array}$ & 90 \\
\hline P072 & Mar del Plata (Buenos Aires) & $\begin{array}{l}\text { B. amyloliquefaciens } \\
\text { B. coagulans } \\
\text { B. megaterium } \\
\text { B. pumilus }\end{array}$ & $\begin{array}{c}30 \\
30 \\
30 \\
120\end{array}$ & 210 \\
\hline P073 & Santiago del Estero & P. alvei & 30 & 30 \\
\hline P074 & Mar del Plata (Buenos Aires) & B. cereus s.s. & 30 & 30 \\
\hline P075 & Santiago del Estero & $\begin{array}{l}\text { B. megaterium } \\
\text { B. subtilis } \\
\text { B. thuringiensis } \\
\text { L. sphaericus } \\
\text { R. stabekisii }\end{array}$ & $\begin{array}{l}30 \\
60 \\
30 \\
60 \\
30\end{array}$ & 210 \\
\hline P076 & La Plata (Buenos Aires) & $\begin{array}{l}\text { B. cereus s.s. } \\
\text { B. licheniformis } \\
\text { B. simplex } \\
\text { B. subtilis } \\
\text { B. thuringiensis } \\
\text { R. stabekisii }\end{array}$ & $\begin{array}{l}30 \\
30 \\
30 \\
30 \\
30 \\
30\end{array}$ & 180 \\
\hline P077 & Villa Iris (Buenos Aires) & B. licheniformis & 60 & 60 \\
\hline P078 & Villarino (Buenos Aires) & $\begin{array}{l}\text { B. megaterium } \\
\text { B. subtilis }\end{array}$ & $\begin{array}{l}60 \\
60\end{array}$ & 120 \\
\hline PO79 & Bahía Blanca (Buenos Aires) & B. cereus s.s. & 30 & 30 \\
\hline P080 & Bahía Blanca (Buenos Aires) & $\begin{array}{l}\text { B. megaterium } \\
\text { P. amylolyticus } \\
\text { P. polymyxa }\end{array}$ & $\begin{array}{l}60 \\
30 \\
30\end{array}$ & 120 \\
\hline P081 & Puerto Madryn (Chubut) & B. subtilis & 30 & 30 \\
\hline
\end{tabular}




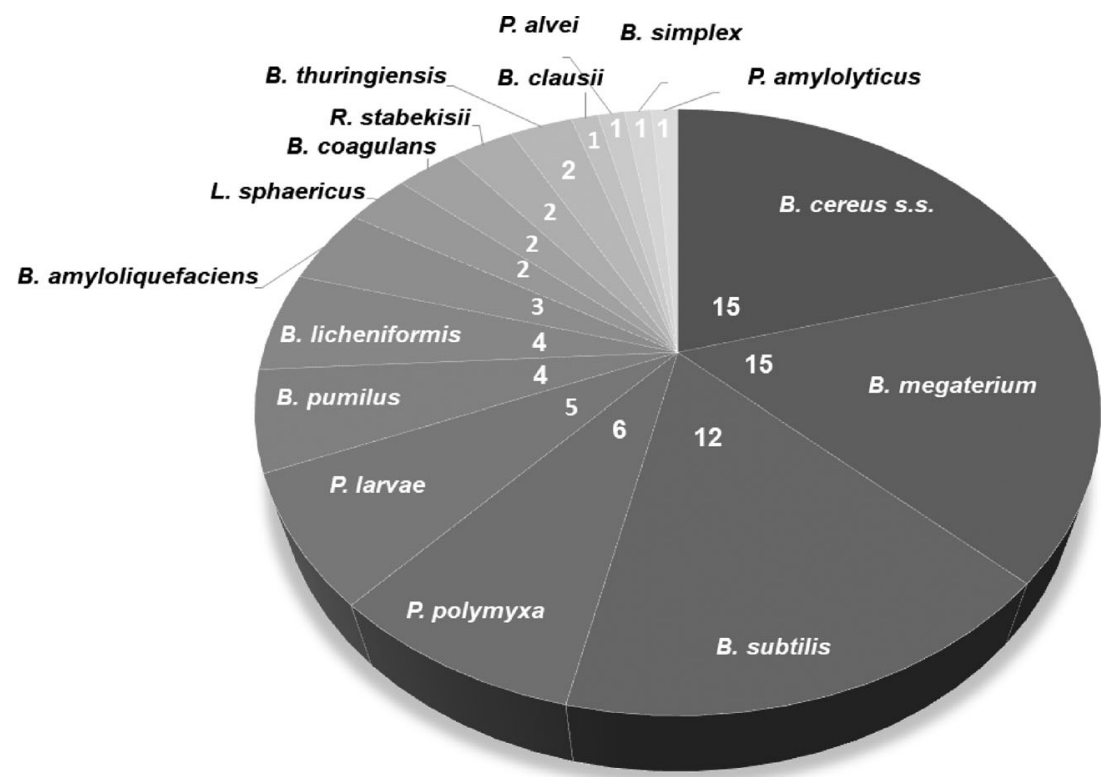

Figure 1. Diversity of species of aerobic spore-forming bacteria isolated from 30 bee pollen samples from Argentina. Numbers in the graph indicate the number of pollens containing each species.

\section{Statistics}

To evaluate if the geographical origin (GO) and bacterial composition (BC) of the bee pollen samples were correlated, we calculated individual sample distances for the $B C$ data (BC distance) based on the genetic distances defined by Huff et al. (1993). On the other hand, to measure the physical distance between $\mathrm{GO}$, we estimated a geographical distance (GGD) for latitude by the Mantel test of matrix correspondence (Matrix, 1967; Smouse et al., 1986). Statistical significance was determined by random permutation, with the number of permutations set to 1,000 . All the analyses were done with GenAIEx 6.5 software (Peakall \& Smouse, 2006, 2012).

\section{Results}

The quality of bee pollen is influenced by the bees at pollen collection (Campos et al., 2010). Thus, in the present study, a total of 30 fresh bee pollen samples collected from the main producing areas of Argentina were analyzed to detect the diversity of aerobic sporeforming bacteria. We identified 73 isolates belonging to 16 different species through isolation on selective and differential media, morphological and biochemical tests, and PCR and RFLP analysis of genes encoding 16S rRNA.

The combination of HiCrome Bacillus agar with a selection of microbiological tests (Alippi, 2019; Alippi \& Abrahamovich, 2019) plus a PCR-RFLP assay (López \& Alippi, 2019) were adapted for reliable identification of al aerobic-spore forming species found in bee pollen samples. Also, the technique used to identify P. larvae was satisfactory for the detection of the foulbrood pathogen in bee pollen samples.
At the bacterial species level, taking into account the total of samples analyzed, the most abundant were Bacillus cereus sensu stricto that was present in $50 \%$ of the samples tested, followed by Bacillus megaterium (40\%), Bacillus subtilis (40\% of the samples), Paenibacillus polymyxa (20\%), Paenibacillus larvae (17\%), Bacillus pumilus (13\%), Bacillus licheniformis (13\%), and Bacillus amyloliquefaciens (10\%), respectively. In a minor proportion, Lysinibacillus sphaericus (7\%), Bacillus coagulans (7\%), Rummelliibacillus stabekisii (7\%), Bacillus thuringiensis (7\%), Bacillus clausii (3\%), Paenibacillus alvei (3\%), Bacillus simplex (3\%), and Paenibacillus amylolyticus (3\%) were also found (Table 1 and Figure 1). It is necessary to point out that many pollen samples contained more than one bacterial species.

We also observed a lack of correlation between bacterial composition and the geographical origin of bee pollen samples. The results of the statistical analysis demonstrated that the bacterial composition of bee pollen samples showed a low correlation with their geographical origin $(r=0.261, P=0.049)$ (Figure 2).

The species composition per bee pollen sample is summarized in Table 1. In nine samples, only one bacterial species was present, i.e., PO9, PO16, PO74, and PO79 containing B. cereus s.s.; $\mathrm{PO} 12$ containing B. megaterium, PO15 containing L. sphaericus; PO73 containing P. alvei; PO77 containing $B$. licheniformis and PO81 containing $B$. subtilis, respectively whereas the rest $(\mathrm{N}=21)$ harbored between two and six different species. Colony-forming unit counts were also variable ranging between $30 \mathrm{CFU} /$ $\mathrm{g}$ (detection limit of the technique) and 2,070 CFU/g.

\section{Discussion}

We analyzed 30 fresh bee pollen samples obtained from the main producing areas of Argentina to 


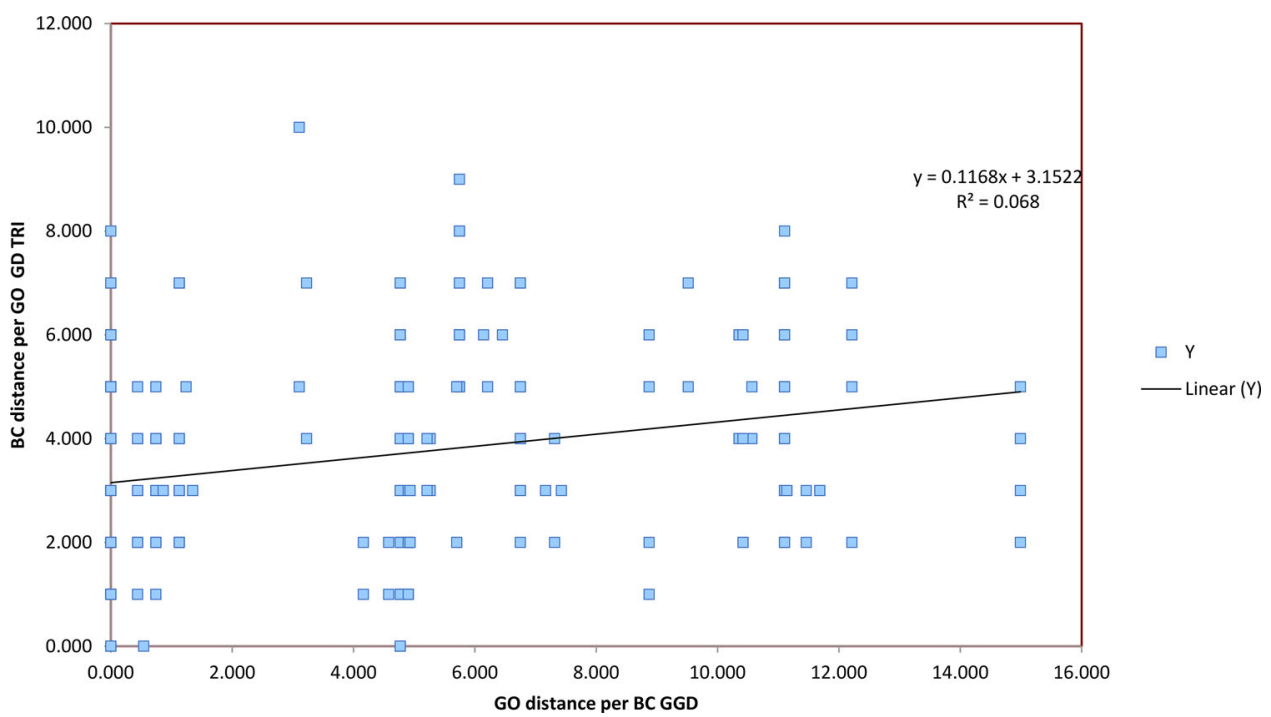

Figure 2. Mantel test of correlation between bacterial composition (BC) and geographical origin distances (GGD) for 30 bee pollen samples from Argentina.

identify aerobic-spore-forming bacteria. We obtained 73 isolates belonging to 16 different species, i.e., $B$. amyloliquefaciens, B. cereus s.s., B. clausii, B. coagulans, $B$. licheniformis, $B$. megaterium, $B$. pumilus, $B$. simplex, B. subtilis, B. thuringiensis, P. alvei, P. amylolyticus, P. larvae, P. polymyxa, L. sphaericus, and R. stabekisii. A lack of correlation between bacterial composition and the geographical origin of bee pollen samples was observed. Some researchers also reported that pollen microbiota is independent of environmental conditions and plant species (Ambika Manirajan et al., 2016; Junker \& Keller, 2015; McFrederick \& Rehan, 2016; Obersteiner et al., 2016), while others suggest that geographical distance and mix of different pollen types influence the bacterial composition of the samples (Moreno Andrade et al., 2019). In a study analyzing the bacterial composition of bee pollen and bee bread from the USA, Gilliam (1979) found that 33 out of the 41 Bacillus isolates obtained were $B$. subtilis, and the rest belonged to Bacillus megaterium, B. licheniformis, B. pumilus, and $B$. circulans, respectively. Regarding pollen from stingless bees (Melipona fasciata), Gilliam and coworkers only found B. megaterium (Gilliam et al., 1990). Recently, Álvarez Hidalgo et al. (2020) have reported 14 different species of Bacillus and six of Paenibacillus isolated from commercial pollen samples from Mexico. They found that the most prevalent species, even after treatment at high gamma irradiation doses, were $B$. pumilus, B. licheniformis, $B$. cereus, $B$. megaterium, $B$. subtilis, $B$. amyloliquefaciens, $B$. vallismortis, $B$. endophyticus, and $P$. cookie; suggesting that irradiation could enhance the selection of irradiation-resistant bacterial strains (Álvarez Hidalgo et al., 2020). Besides, in commercial pollen purchased in Egypt, the most radio-resistant bacteria, after treatment of $5.0 \mathrm{kGy}$, were Bacillus megaterium,
Bacillus pumilus, and Bacillus subtilis (Hosny et al., 2018). On the other hand, Dinkov (2018) reported that within Bacilli, B. pumilus and B. subtilis were the most prevalent species contaminating bee pollen; $B$. pumilus contaminated both fresh and dried pollen whereas $B$. subtilis was only present in fresh pollen samples from Bulgaria. Another study, using a tRNA Cys-PCR-based approach, examined commercial bee pollen samples from Mexico revealing that $3 \%$ of the endospore-forming colonies isolated from commercial bee pollen were related to B. cereus s.l. (Hernández Flores et al., 2020). That analysis identified members of the genus Bacillus as the most common species found in association with commercial bee pollen, followed by Paenibacillus species. Besides $B$. cereus, other identified species were $B$. licheniformis, B. pumilus, B. subtilis, $B$. sonorensis $B$. subtilis, $B$. mojavensis, $B$. megaterium, $B$. altitudinis, $B$. endophytiCus, P. odorifer, P. chitinolyticus, P. peoriae, P. polymyxa and, $P$. rhizosphaeriae (Hernández Flores et al., 2020). In Germany, B. subtilis, B. cereus L. sphaericus, Brevibacillus brevis, and $P$. alvei were isolated from grass pollen (Heydenreich et al., 2012).

The microbiota of spore-forming bacteria isolated from bee pollen in Argentina was similar to those reported by other authors in different countries (Dinkov, 2018; Gilliam, 1979; Gilliam et al., 1990; Hernández Flores et al., 2020; Heydenreich et al., 2012). Nevertheless, to our knowledge, the present study is the first report of the presence of viable spores of B. clausii, B. coagulans, B. simplex, and $R$. stabekisii in bee pollen.

It has been recorded that AFB disease of honey bees can be transmitted between honey bee colonies by feeding pollen contaminated with bacterial spores of P. larvae (Gochnauer \& Corner, 1974). Also, other authors reported contamination of pollen with 
P. larvae spores in different European countries, Mexico, and Chile (Bakonyi et al., 2003; de Sousa Pereira et al., 2019; Moreno Andrade et al., 2019; Šekulja et al., 2014). However, the incidence of $P$. larvae spores in bee pollen samples from Argentina was higher $(17 \%)$ than in those studies. A higher incidence of spores of $P$. larvae in honey compared to bee pollen should be expected. AFB spores found in dead pupae and dried scales are spread throughout the hive as the bees, trying to remove dead larvae, contaminate brood food, and consequently, nectar and honey stored in those cells will contain spores (Ratnieks, 1992). Also, foraging for pollen and nectar exposes bees to parasites that are horizontally transmitted via flowers, including $P$. larvae.

According to Anjos et al. (2019), frozen bee pollen is better than dried pollen regarding its nutritional value. However, due to the lower microbiological contamination, dried bee pollen is a safer option to use in the human diet. Nevertheless, pollen should be tested to comply with standards for microbiological purity (Bogdanov, 2006). In Argentina, according to the Código Alimentario Argentino (Argentinean Food Code), pollen should be consumed dried, should not exceed the maximum limit of aerobic bacteria of $1.5 \times 10^{5} \mathrm{CFU} / \mathrm{g}$, and should be free from pathogenic microorganisms (Código Alimentario Argentino, 2019).

Our results showed that the microbiota of sporeforming bacteria isolated from bee pollen in Argentina was also similar to those reported for honey and floral nectar by other authors (AizenbergGershtein et al., 2013; Alippi et al., 2004; Alippi \& Abrahamovich, 2019; Iurlina \& Fritz, 2005; Piccini et al., 2004; Pomastowski et al., 2019; Sinacori et al., 2014). Also, bee pollen can carry honey bee diseases due to the presence of viable spores of $P$. larvae and also can carry spores of toxicogenic $B$. cereus s.s. and $B$. megaterium strains which were the most abundant species found. These results contribute to the knowledge of the diversity of bacteria associated with bee pollen, emphasizing the importance of microbial control during pollen production intended for human consumption.

\section{Acknowledgments}

We wish to thank to F. Ayuch, E. Bordeau, L. De Feudis, J. M. Echazarreta, S. Fuselli, D. García, C. Gonzáles, D. laconis, L. Leniz, F. López, M. Marcos, P. Raposo, F. Saldungaray, C. Teyseire, and F. Walker for providing pollen samples. We also thank A. Garayalde for the statistical analysis.

\section{Disclosure statement}

The authors declare no conflicts of interest.

\section{Funding}

This research was partially supported by ANPCyT Argentina (Grant No. PICT 2017-2014). AMA is a Member of the Scientific Research Career of CICBA, Argentina, and $A C L$ and LAF are members of the Scientific Research Career of CONICET, Argentina, respectively.

\section{ORCID}

Adriana M. Alippi (D) http://orcid.org/0000-0003-4749-1567 Leticia A. Fernández (D) http://orcid.org/0000-0003-3785-8003 Ana C. López (ID) http://orcid.org/0000-0002-7064-9652

\section{References}

Aizenberg-Gershtein, Y., Izhaki, I., \& Halpern, M. (2013). Do honeybees shape the bacterial community composition in floral nectar? PLoS One, 8(7), e67556. https://doi.org/ 10.1371/journal.pone.0067556

Alippi, A. M. (2019). Data associated with the characterization and presumptive identification of Bacillus and related species isolated from honey samples by using HiCrome Bacillus agar. Data Brief, 25, 104206. https://doi. org/10.1016/j.dib.2019.104206

Alippi, A. M., \& Abrahamovich, E. (2019). HiCrome Bacillus agar for presumptive identification of Bacillus and related species isolated from honey samples. International Journal of Food Microbiology, 305, 108245. https://doi.org/10.1016/j.ijfoodmicro.2019.108245

Alippi, A. M., \& Aguilar, O. M. (1998). Characterization of isolates of Paenibacillus larvae subsp. larvae from diverse geographical origin by the polymerase chain reaction and Box primers. Journal of Invertebrate Pathology, 72(1), 21-27. https://doi.org/10.1006/jipa.1998.4748

Alippi, A. M., Reynaldi, F. J., López, A. C., De Giusti, M. R., \& Aguilar, O. M. (2004). Molecular epidemiology of Paenibacillus larvae larvae and incidence of American Foulbrood in Argentinean honeys from Buenos Aires Province. Journal of Apicultural Research, 43(3), 135-143. https://doi.org/10.1080/00218839.2004.11101124

Almeida-Muradian, L. B., Pamplona, L. C., Coimbra, S., \& Barth, O. M. (2005). Chemical composition and botanical evaluation of dried bee pollen pellets. Journal of Food Composition and Analysis, 18(1), 105-111. https://doi.org/ 10.1016/j.jfca.2003.10.008

Álvarez Hidalgo, E., Hernandez-Flores, J. L., Andrade Moreno, V. D., Ramos López, M., Romero Gómez, S. Vázquez Cruz, M. A., Torres Ruíz, A., Alvarado Osuna, C., Jones, G. H., Arvizu Hernández, I., Estrada Martínez, A., \& Campos-Guillén, J. (2020). Gamma irradiation effects on the microbial content in commercial bee pollen used for bumble bee mass rearing. Radiation Physics and Chemistry, 168, 108511. https://doi.org/10.1016/j.radphyschem.2019.108511

Ambika Manirajan, B., Ratering, S., Rusch, V., Schwiertz, A., Geissler-Plaum, R., Cardinale, M., \& Schnell, S. (2016). Bacterial microbiota associated with flower pollen is influenced by pollination type and shows a high degree of diversity and species-specificity. Environmental Microbiology, 18(12), 5161-5174. https://doi.org/10.1111/ 1462-2920.13524

Anjos, O., Paula, V., Delgado, T., \& Estevinho, L. M. (2019). Influence of the storage conditions on the quality of bee pollen. Zemdirbyste-Agriculture, 106(1), 87-94. https://doi.org/10.13080/z-a.2019.106.012 
Bakonyi, T., Derakhshifar, I., Grabensteiner, E., \& Nowotny, N. (2003). Development and evaluation of PCR assays for the detection of Paenibacillus larvae in honey samples: Comparison with isolation and biochemical characterization. Applied and Environmental Microbiology, 69(3), 1504-1510. https://doi.org/10.1128/AEM.69.3.1504-1510. 2003

Bertoncelj, J., Polak, T., Pucihar, T., Lilek, N., Kandolf Borovšak, A., \& Korošec, M. (2018). Carbohydrate composition of Slovenian bee pollens. International Journal of Food Science \& Technology, 53(8), 1880-1888. https:// doi.org/10.1111/ijfs.13773

Bogdanov, S. (2006). Contaminants of bee products. Apidologie, 37(1), 1-18. https://doi.org/10.1051/apido:2005043

Bucio Villalobos, C. M., López Preciado, G., Oscar Alejandro Martínez Jaime, O. A., \& Morales, J. J. (2014). Microflora asociada a granos de polen recolectados por abejas domésticas (Apis mellifera L). Nova Scientia, 2(4), 93-103. https://doi.org/10.21640/ns.v2i4.212

Campos, M. G. R., Frigerio, C., Lopes, J., \& Bogdanov, S. (2010). What is the future of bee-pollen? Journal of ApiProduct and ApiMedical Science, 2(4), 131-144. https://doi.org/10.3896/IBRA.4.02.4.01

Código Alimentario Argentino. (2019). Capítulo X, Alimentos azucarados. www.alimentosargentinos.gov.ar/contenido/ marco/CAA/Capitulo_X

de Graaf, D. C., Alippi, A. M., Antúnez, K., Aronstein, K. A., Budge, G., De Koker, D., De Smet, L., Dingman, D. W., Evans, J. D., Foster, L. J., Fünfhaus, A., Garcia-Gonzalez, E., Gregore, A., Human, H., Murray, K. D., Nguyen, B. K., Poppinga, L., Spivak, M., van Engelsdorp, D., Wilkins, S., \& Genersch, E. (2013). Standard methods for American foulbrood research. Journal of Apicultural Research, 52(1), 1-28. https://doi.org/10.3896/IBRA.1.52.1.11

de Sousa Pereira, K., Meeus, I., \& Smagghe, G. (2019). Honey bee-collected pollen is a potential source of Ascosphaera apis infection in managed bumble bees. Scientific Reports, 9, 1-9.

Denisow, B., \& Denisow-Pietrzyk, M. (2016). Biological and therapeutic properties of bee pollen: A review. Journal of the Science of Food and Agriculture, 96(13), 4303-4309. https://doi.org/10.1002/jsfa.7729

Dingman, D. W., \& Stahly, D. P. (1983). Medium promoting sporulation of Bacillus larvae and metabolism of medium components. Applied and Environmental Microbiology, 46(4), 860-869. https://doi.org/10.1128/ aem.46.4.860-869.1983

Dinkov, D. (2018). Bacterial contamination of vacuum stored flower bee pollen. Journal of Microbiology, Biotechnology and Food Sciences, 7(3), 387-391. https:// doi.org/10.15414/jmbfs.2018.7.4.387-391

Feás, X., Vázquez-Tato, M. P., Estevinho, L. M., Seijas, J. A., \& Iglésias, A. (2012). Organic bee pollen: Botanical origin, nutritional value, bioactive compounds, antioxidant activity and microbiological quality. Molecules, 17(7), 8359-8377. https://doi.org/10.3390/molecules17078359

Fernández, L. A., Tromba, J. S., Alippi, A. M., López, F. M., Pérez, M., \& Gallez, L. M. (2020). Microbiological and chemical characterization of bee pollen throughout the production process in the Southwest of Buenos Aires Province (Argentina). Journal of Apicultural Research, 59(2), 156-159. https://doi.org/10.1080/00218839.2019. 1702327

Genersch, E. (2010). American Foulbrood in honeybees and its causative agent, Paenibacillus larvae. Journal of
Invertebrate Pathology, 103, S10-S19. https://doi.org/10. 1016/j.jip.2009.06.015

Gilliam, M. (1979). Microbiology of pollen and bee bread: The genus Bacillus. Apidologie, 10(3), 269-274. https:// doi.org/10.1051/apido:19790304

Gilliam, M., Roubik, D. W., \& Lorenz, B. J. (1990). Microorganisms associated with pollen, honey, and brood provisions in the nest of a stingless bee, Melipona fasciata. Apidologie, 21(2), 89-97. https://doi.org/10. 1051/apido:19900201

Gochnauer, T. A., \& Corner, J. (1974). Detection and identification of Bacillus larvae in a commercial sample of bee-collected pollen. Journal of Apicultural Research, 13(4), 265-267. https://doi.org/10.1080/00218839.1974. 11099790

González, G., Hinojo, M. J., Mateo, R., Medina, A., \& Jiménez, M. (2005). Occurrence of mycotoxin producing fungi in bee pollen. International Journal of Food Microbiology, 105(1), 1-9. https://doi.org/10.1016/j.ijfoodmicro.2005.05.001

Govan, V. A., Allsopp, M. H., \& Davison, S. (1999). A PCR detection method for rapid identification of Paenibacillus larvae. Applied and Environmental Microbiology, 65(5), 2243-2245. https://doi.org/10.1128/AEM.65.5.2243-2245.1999

Gücükoğlu, A., Saka, E., Uyanik, T., Kanat, S., Çadirci, Ö., \& Akpinar, R. (2020). Determination of $C$. botulinum presence in pollen samples collected from different regions of Turkey by real-time PCR. LWT, Food Science and Technology, 134, 110172. https://doi.org/10.1016/j.lwt. 2020.110172

Hernández Flores, J. L., Salinas Landaverde, D., Pacheco Huerta, Y., Guerra Castillo, V. L., Barrios Sánchez, M. D. L. Á., Arvizu Hernández, I., Ramos López, M. A., Alvarez Hidalgo, E., Jones, G. H., \& Campos, G. J. (2020). Phylogenetic Analysis of Bacillus cereus sensu lato isolates from commercial bee pollen using tRNACys-PCR. Microorganisms, 8, 524. https:// doi.org/10.3390/microorganisms8040524

Heydenreich, B., Bellinghausen, I., König, B., Becker, W. M., Grabbe, S., Petersen, A., \& Saloga, J. (2012). Gram-positive bacteria on grass pollen exhibit adjuvant activity inducing inflammatory $\mathrm{T}$ cell responses. Clinical and Experimental Allergy, 42(1), 76-84. https://doi.org/10. 1111/j.1365-2222.2011.03888.x

Hosny, A. S., Sabbah, F. M., \& El-Bazza, Z. E. (2018). Studies on the microbial decontamination of Egyptian bee pollen by ${ }^{\circ} \gamma$ radiation. Egyptian Pharmaceutical Journal, 17, 190-200.

Huff, D. R., Peakall, R., \& Smouse, P. E. (1993). RAPD variation within and among natural populations of outcrossing buffalograss [Buchloe dactyloides]. Theoretical and Applied Genetics, 86(8), 927-934. https://doi.org/10.1007/ BF00211043

Iurlina, M. O., \& Fritz, R. (2005). Characterization of microorganisms in Argentinean honeys from different sources. International Journal of Food Microbiology, 105(3), 297-304. https://doi.org/10.1016/j.ijfoodmicro.2005.03.017

Johnson, E. A., \& Bradshaw, M. (2001). Clostridium botulinum and its neurotoxins: A metabolic and cellular perspective. Toxicon, 39(11), 1703-1722. https://doi.org/10. 1016/S0041-0101(01)00157-X

Junker, R. R., \& Keller, A. (2015). Microhabitat heterogeneity across leaves and flower organs promotes bacterial diversity. FEMS Microbiology Ecology, 91(9), fiv097. https://doi.org/10.1093/femsec/fiv097

Kieliszek, M., Piwowarek, K., Kot, A. M., Błażejak, S., Chlebowska-Śmigiel, A., \& Wolska, I. (2018). Pollen and 
bee bread as new health-oriented products: A review. Trends in Food Science \& Technology, 71, 170-180. https://doi.org/10.1016/j.tifs.2017.10.021

López, A. C., \& Alippi, A. M. (2010). Enterotoxigenic gene profiles of Bacillus cereus and Bacillus megaterium isolates recovered from honey. Revista Argentina de Microbiologia, 42(3), 216-225.

López, A. C., \& Alippi, A. M. (2019). Feasibility of using RFLP of PCR-amplified 16S rRNAs for rapid differentiation of aerobic spore-forming bacteria from honey. Journal of Microbiological Methods, 165, 105690. https:// doi.org/10.1016/j.mimet.2019.105690

López, A. C., Fernández, L., \& Alippi, A. M. (2020). Traceability of potential enterotoxigenic Bacillus cereus in bee-pollen samples from Argentina throughout the production process. International Journal of Food Microbiology, 334, 108816. https://doi.org/10.1016/j. ijfoodmicro.2020.108816

López, A. C., Minnaard, J., Pérez, P. F., \& Alippi, A. M. (2013). In vitro interaction between Bacillus megaterium strains and Caco-2 cells. International Microbiology, 16(1), 27-33. Doi: 10.2436/1501.01.177.ISSN 1139-6709

Margăoăn, R., Mărghitaş, L. A., Dezmirean, D., Mihal, C. M. \& Bobis, O. (2010). Bee collected pollen - General aspects and chemical composition. Bulletin of University of Agricultural Sciences and Veterinary Medicine ClujNapoca. Animal Science and Biotechnologies, 67, 1-2.

Mauriello, G., De Prisco, A., Di Prisco, G., La Storia, A., \& Caprio, E. (2017). Microbial characterization of bee pollen from the Vesuvius area collected by using three different traps. PLoS One, 12(9), e0183208. https://doi.org/ 10.1371/journal.pone.0183208

McFrederick, Q. S., \& Rehan, S. M. (2016). Characterization of pollen and bacterial community composition in brood provisions of a small carpenter bee. Molecular Ecology, 25(10), 2302-2311. https://doi.org/10.1111/mec. 13608

Moreno Andrade, V. D., Gutiérrez, C. S., Medina Calvillo, R. P., Cruz Hernández, A., Cruz, M. A. V., Ruíz, A. T., Riomero Gómez, S., Ramos López, M. A., Alvarez Hidalgo, E., López-Gaytán, S. B., Ramirez, N. S., Jones, G. H., Hernández Flores, J. L., \& Campos Guillén, J. (2018). Microbial diversity in commercial bee pollen from Europe, Chile, and Mexico, based on 16S rRNA gene amplicon metagenome sequencing. Genome Announcements, 6(20), e00247-18. https://doi.org/10. 1128/genomeA.00247-18

Moreno Andrade, V. D., Hernández Flores, J. L., Ramos López, M. A., Cruz Hernández, A., Romero Gómez, S., Medina Calvillo, R. P., Estrada Martínez, A. G., Caballero Pérez, J., Arvizu Hernández, I., Alvarez Hidalgo, E., Alvarado Osuna, C., Jones, G. H., \& Campos Guillén, J. (2019). Evaluation of the presence of Paenibacillus larvae in commercial bee pollen using PCR amplification of the gene for tRNA ${ }^{\text {Cys }}$. Brazilian Journal of Microbiology, 50(2), 471-480. https://doi.org/10.1007/s42770-019-00039-9

Obersteiner, A., Gilles, S., Frank, U., Beck, I., Häring, F., Ernst, D., Rothballer, M., Hartmann, A., Traidl-Hoffmann, C., \& Schmid, M. (2016). Pollen-associated microbiome correlates with pollution parameters and the allergenicity of pollen. PLoS One, 11(2), e0149545. https://doi. org/10.1371/journal.pone. 0149545

OIE- World Organization for Animal Health. (2018). American foulbrood of honey bees (Infection of honey bees with Paenibacillus larvae). In OIE. Manual of diagnostic tests and vaccines for terrestrial animals (Chapter 3.2.2, pp. 719-735). https://www.oie.int/fileadmin/Home/eng/Health_standards/ tahm/3.02.02_AMERICAN_FOULBROOD.pdf

Peakall, R. O. D., \& Smouse, P. E. (2006). GENALEX 6: Genetic analysis in Excel. Population genetic software for teaching and research. Molecular Ecology Notes, 6(1), 288-295. https://doi.org/10.1111/j.1471-8286.2005.01155.x

Peakall, R., \& Smouse, P. E. (2012). GENALEX 6.5: Genetic analysis in EXCEL. Population genetic software for teaching and research-an update. Bioinformatics, 28(19), 2537-2539. https://doi.org/10.1093/bioinformatics/bts460

Piccini, C., Antúnez, K., \& Zunino, P. (2004). An approach to the characterization of the honey bee hive bacterial flora. Journal of Apicultural Research, 43(3), 101-104. https://doi.org/10.1080/00218839.2004.11101118

Puig-Peña, Y., del-Risco-Ríos, C. A., Álvarez-Rivera, V., LeivaCastillo, V., \& García-Neninger, R. (2012). Comparación de la calidad microbiológica del polen apícola fresco y después de un proceso de secado. CENIC Ciencias Biológicas, 43, 23-27.

Pomastowski, P., Złoch, M., Rodzik, A., Ligor, M., Kostrzewa, M., \& Buszewski, B. (2019). Analysis of bacteria associated with honeys of different geographical and botanical origin using two different identification approaches: MALDI-TOF MS and 16S rDNA PCR technique. PLoS One, 14(5), e0217078. https://doi.org/10.1371/journal.pone. 0217078

Ratnieks, F. L. (1992). American foulbrood: The spread and control of an important disease of the honey bee. Bee World, 73(4), 177-191. https://doi.org/10.1080/0005772X. 1992.11099136

Rzepecka-Stojko, A., Stojko, J., Kurek-Górecka, A., Górecki, M., Kabała-Dzik, A., Kubina, R., Moździerz, A., \& Buszman, E. (2015). Polyphenols from bee pollen: Structure, absorption, metabolism and biological activity. Molecules, 20(12), 21732-21749. https://doi.org/10.3390/ molecules201219800

Šekulja, D., Pechhacker, H., \& Licek, E. (2014). Drifting behavior of honey bees (Apis Mellifera Carnica Pollman, 1879 ) in the epidemiology of American foulbrood. Zbornik Veleučilišta u Rijeci, 2, 345-358.

Sinacori, M., Francesca, N., Alfonzo, A., Cruciata, M., Sannino, C., Settanni, L., \& Moschetti, G. (2014). Cultivable microorganisms associated with honeys of different geographical and botanical origin. Food Microbiology, 38, 284-294. https://doi.org/10.1016/j.fm. 2013.07.013

Smouse P. E., Long J. C., Sokal, R. R. (1986). Multiple regression and correlation extensions of the Mantel test of matrix correspondence. Systematic Zoology, 35, 627-632.

Soares de Arruda, V. A., Vieria dos Santos, A., Figueiredo Sampaio, D., da Silva Araujo, E., de Castro Peixoto, A. L., Estevinho, M. L. F., \& Almeida Muradián, L. B. (2017) Microbiological quality and physicochemical characterization of Brazilian bee pollen. Journal of Apicultural Research, 56(3), 231-238. https://doi.org/10.1080/00218839.2017.1307715

Stenfors Arnesen, L. P., Fagerlund, A., \& Granum, P. E. (2008), From soil to gut: Bacillus cereus and its food poisoning toxins. FEMS Microbiology Reviews, 32(4), 579-606. https://doi. org/10.1111/j.1574-6976.2008.00112.x

Thakur, M., \& Nanda, V. (2020). Composition and functionality of bee pollen: A review. Trends in Food Science \& Technology, 98, 82-106. https://doi.org/10.1016/j.tifs. 2020.02.001 